\title{
Cytotoxic Test of Octopus cyanea Ink Extract
}

\author{
John Dominggus Kalor ${ }^{*}$, Eva Susanty Simaremare ${ }^{2}$, Allowisya Futwembun ${ }^{3}$, \\ Gloria Wabiser², Elsye Gunawan², Yuliana Rut Yabansabra ${ }^{3}$ \\ 1 Departement of Marine Scinece, Cenderawasih University, Jayapura Papua, Indonesia \\ 2 Departement of Pharmacy, Cenderawasih University, Jayapura Papua, Indonesia \\ 3 Departement of Chemistry, Cenderawasih University, Jayapura Papua, Indonesia \\ * Corresponding author's e-mail: john_pela@yahoo.com
}

\begin{abstract}
Marine biodiversity of Papua is very high, but unfortunately research and utilization in medicine are limited. Many species of flora and fauna are used in ethopharmacology as drugs but without scientific explanation, e.g. octopus (Octopus cyanea), found in the Northern Papua Sea. The aim of this research was to test the toxicity of the ethanol octopus ink. The toxicity was tested with the Brine Shrimp Lethality Test (BSLT) method. The samples were collected from the sea of Biak island in West Papua, extracted with ethanol, ethyl acetate, and dichloromethane then tested the toxicity for Artemia salina leach larvae. The toxicity test involved concentrations of 1000, 750, 500, 250, $100,75,50$, and $25 \mathrm{ppm}$. The result showed that ethanol extract of octopus ink has $\mathrm{LC}_{50}$ of $290 \mathrm{ppm}$, ethyl acetate extract has $\mathrm{LC}_{50}$ of $947 \mathrm{ppm}$, whereas dicholoromethane extract - $2190 \mathrm{ppm}$.
\end{abstract}

Keywords: toxicity, Octopus cyanea, Artemia salina leach, $\mathrm{LC}_{50}$

\section{INTRODUCTION}

Papua island is very high in marine and coastal biodiversity. So far, this marine and coastal biodiversity of Papua has only been used for the fulfillment of protein, economic, and tourism needs. On the other hand, the Papuan sea actually has special potential value from that biodiversity which has not been touched and has very high economic value, including the pharmacological potential to utilize marine biological materials as medicines in the future.

The study of new marine medicinal compounds has been conducted in several places in Eastern Indonesia such as South Sulawesi, Maluku and several other provinces. Although the marine territory of Papua is so vast and rich, marine pharmacy research is very rare and has not even been conducted on the island of Papua. The search for new anti-cancer drugs is intensively conducted today. This is because cancer is a deadly disease and there is no drug that can reliably cure it. Although the success rates in cancer therapy are on the rise, modern therapies such as surgery, chemotherapy or radiation vary in success, depending on the stage of the tumor / cancer type.

It turns out that the ethno-pharmacology of Maluku (Tepa Islands, Southeast Maluku) and Papua have also used octopus ink to effectively eliminate breast cancer. Octopus cyane is the same mollusk class as squid and cuttlefish (Martinez, 2013) and is found abundantly in the waters of Eastern Indonesia, especially Papua. Octopus has a liquid called ink that serves to outwit predators. This ink is a natural melamine (melanoprotein) alkaloid containing $10-15 \%$ of lysosome proteins capable of killing cells. Ink can kill pathogenic bacteria such as Staphylococcus aureus (Posangi et al, 2013) so the octopus can potentially be used as an anti-cancer drug. 


\section{MATERIAL AND METHODS}

\section{Materials}

The tools used in this research were analytical scales, glassware, scissors, brown bottle, vials, vacum rotary evaporator, cooler, separating funnel, hatchery and aerator. The utilized chemicals were $96 \%$ ethanol, dichloromethane, ethanol, ethyl acetate, shrimp larvae A. Salina, DMSO, seawater, and reagents.

\section{Sample collection}

The samples were taken from the sea of Biak Island West Papua, collected and poured into an ice box. The octopus was washed with running water and then surgery was performed to extract the ink. The ink pouch was collected in a sterile bottle, then stored in a refrigerator at $-20^{\circ} \mathrm{C}$ before use (Posangi, 2013). Other parts used were placed in other containers and put into a cooler with a temperature of $-20^{\circ} \mathrm{C}$.

\section{Extraction and fractionation of ink}

The sample (ink bag) was gently crushed to remove the ink and the meat. A total of $\pm 45 \mathrm{~mL}$ of each sample was inserted into a separating funnel and $50 \mathrm{~mL}$ dichloromethane was added. The separated mouthpiece occasionally expelled gas in the funnel so the samples were distributed in two phases. The organic phase was accommodated and the water phase was extracted 2 more times with the same method. The second-tiered extraction with the same procedure of the liquid phase (ink) was carried out using an ethyl acetate solvent, and the third one was extracted using methanol solvent in which fraction I (non polar), fraction II (semi polar), and fraction III (polar) were obtained. These three phases were evaporated using a rotary evaporator and a constant fraction to obtain a viscous extract. The subsequent fractions were tested for their cytotoxicity in which the the fraction having high $\mathrm{LC}_{50}$ would be continued.

\section{Isolate ethanol ink extract with column chromatography}

The ethanol extract was purified by means of column chromatography using a columnic silica gel with a mixture of the $\mathrm{N}$-hexane motion phase: ethyl acetate-acetone (1: 4:1). The isolate was collected and then evaporated. The isolates were monitored using a silica gel TLC plate $\mathrm{GF}_{254}$.

\section{Toxicity test}

The extracts and fractions of the test sample were made into a stock solution of $1000 \mathrm{ppm}$. The samples were made of $750,500,250,100,75,50$, and $25 \mathrm{ppm}$ dilutions. The test was performed by inserting 10 48-hour Artemia salina larvae into a vial filled with negative test and control samples, 1-2 drops of $1 \%$ DMSO solution, and seawater with a total of all $5 \mathrm{~mL}$. After 24 hours, dead larvae were calculated with the aid of a magnifying glass device (Nurhayati, 2006). Testing was done in triplicate (Meyer et al. 1982 in Junearti 2009). The obtained $\mathrm{LC}_{50}$ data was calculated with probit method by making curve relation between percentage of inhibition with dose (Fadhli, 2012). For the percentage of larval mortality, it can be calculated by means of the following formula:

If there is an Artemia larvae that is dead on the control, then the formula is used as Abbot's i.e.

$$
\begin{aligned}
\% \text { mortality } & =\frac{M a-M k}{\text { number } \text { of test animal }} \times 100 \% \\
M a & =\text { the mortality test } \\
M k & =\text { mortality control }
\end{aligned}
$$

\section{RESULTS AND DISCUSSION}

\section{Sample preparation}

O.cyanea (Figure 1) is diurnal (active during the day) and as a result the sample was taken during the day. The octopus was taken from the reef at a depth of $\pm 2 \mathrm{~m}$. In the preparation of this sample the octopus's ink bag (Octopus cyane) was squeezed and blended, so that the parts of the ink that were still clumpy were destroyed. Then the sample volume was measured obtaining $45 \mathrm{~mL}$

Organoleptic examination based on the macroscopic observation showed that the octopus had eight tentacles, $45 \mathrm{~cm}$ wide, was $5 \mathrm{~kg}$ in weight and $1 \mathrm{~m}$ long.

\section{Extraction}

The main principle in extracting these octopus ink samples is that the polar compounds will be attracted by the polar solvents (ethanol), the 


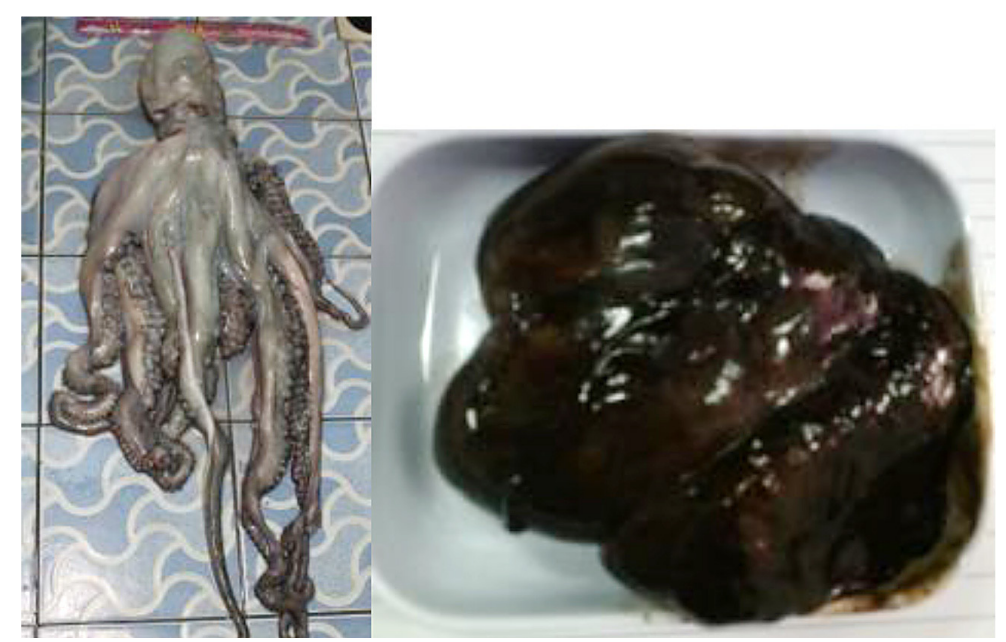

Figure 1. Octopus cyanea (left) and octopus ink (right)

semi-polar compounds will be attracted to the semi-polar (ethyl acetate) solvents and the nonpolar compounds will be attracted to the non-polar solvents (dichloromethane) (Figure 2) and the recovery was shown in Table 1.

\section{Fractionate octopus ink}

Fractionation is a method of separating a mixture comprising several factions with different levels of polarity (Harbone, 2007). Fractionation is needed to separate the main classes containing one of the other main groups. The general method of fractionation is the liquid-liquid extraction and chromatography. The liquid-liquid extraction used for octopus ink fractionation was conducted as follows. First, extraction was done by inserting $45 \mathrm{~mL}$ of octopus ink into a separating funnel and fractionating in succession with a ratio $(1: 1)$ starting from non-polar solvents in the form of n-hexane, then semi-polar solvent in the form of ethyl acetate and followed by polar solvents in the form of ethanol.

The color of the ink extract O.cyanea was different between the three solvents, the n-hexane extract was light orange, ethyl acetate was brownish orange and ethanol was dark brown (Figure 3). Table 1 shows the acquisition value of each extract obtained. This acquisition value is calculated with the aim of assessing how efficient and effective the extraction method used was. The greater the acquisition value, the more chemical compounds extracted.

Then the isolation process was carried out but first the proper mobile phase search for the three extracts was monitored by looking at the profile with TLC (Figure 4). The search was carried out using eluents at different polarity levels to obtain a suitable mobile phase for the results of octopus ink extraction, which was where n-hexane and

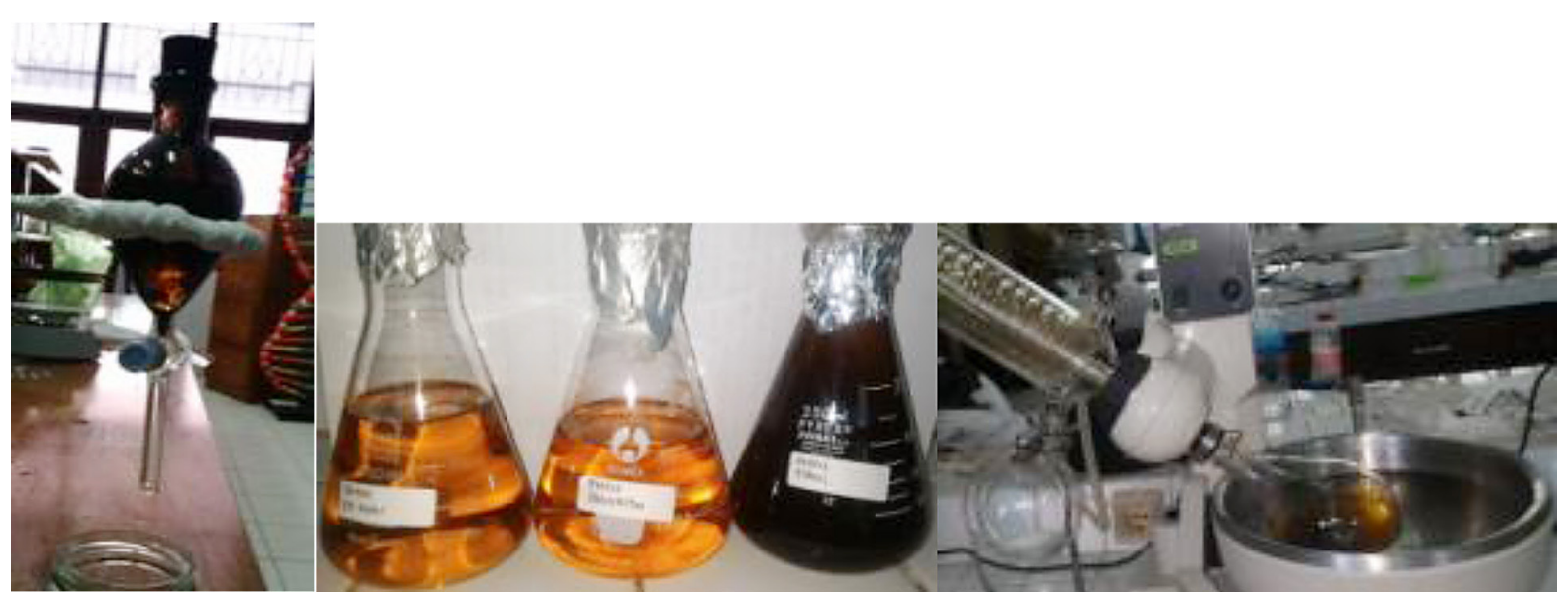

Figure 2. Separation of active compounds from octopus ink (left); extract three types of solvents (middle); and evaporate the solvent with rotavor (right) 
Table 1. Recovery of octopus ink extract by liquid-liquid extraction method

\begin{tabular}{|l|c|c|}
\hline \multicolumn{1}{|c|}{ Solvent } & Weight $(\mathrm{g})$ & Recovery(\%) \\
\hline N-hexane & 0.07 & 0.16 \\
\hline Ethyl acetate & 0.02 & 0.04 \\
\hline Ethanol & 3.59 & 7.98 \\
\hline
\end{tabular}

ethyl acetate got the same mobile phase of n-hexane: ethyl acetate (4:1) and ethanol got the mobile phase n-hexane: ethyl acetate: acetone (1:4:1).

\section{Test of cytotoxic activity of octopus ink fractions with BSLT method}

The BSLT method was carried out by exposure to the extract solution of the compound tested on Artemia salina Leach larvae. In other words, the extract solution of the compound must dissolve completely in the medium of live A. salina larvae, namely sea water, so that the sample concentration obtained represented the actual sample concentration (Mardanny, 2015). The seawater used in this study came from the Amai Village (Depapre), because most of the sea in Papua is still good and not severely polluted; one of them is located in the Amai Village. The $\mathrm{pH}$ level measured using the $\mathrm{pH}$ indicator was 8 . This showed that the seawater from Amai was still very good to use because it was close to $\mathrm{pH} 8$ (where larvae live). The effect of extracts on each solvent with various concentrations of A.salina larvae can be seen in the following Table 2.

On the basis of the results of BSLT testing, it can be seen in Table 3 where the concentration of each octopus ink extract in this study had a different effect on the death of Artemia larvae. in the ethanol extract, $266 \mathrm{ppm}$ concentration caused a $50 \%$ average mortality of larvae, compared to 947 ppm of the ethyl acetate extract and $2190 \mathrm{ppm}$ of dichloromethane (Table 3). Due to the ethanol extract having a toxic $\mathrm{LC}_{50}$ value, it continued to process isolation.

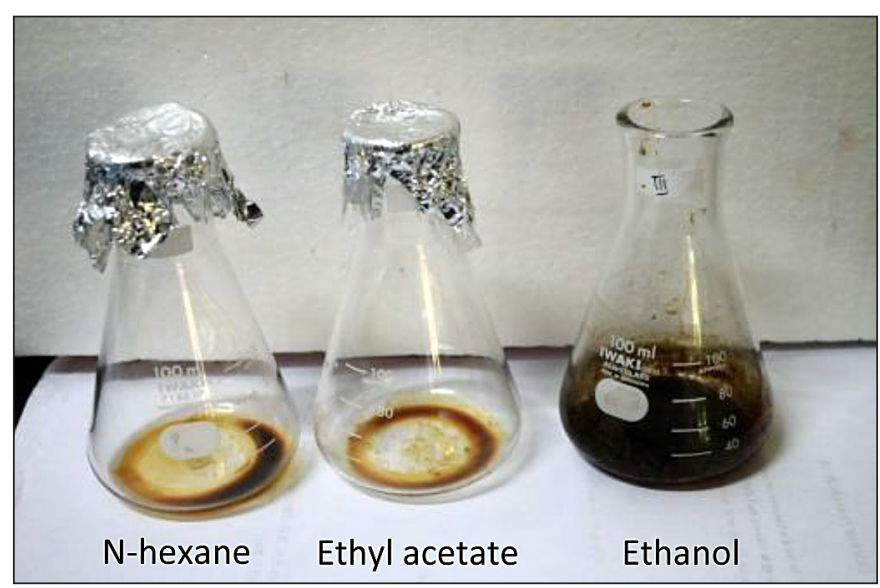

Figure 3. Results of extraction of octopus ink by liquid-liquid extraction method.

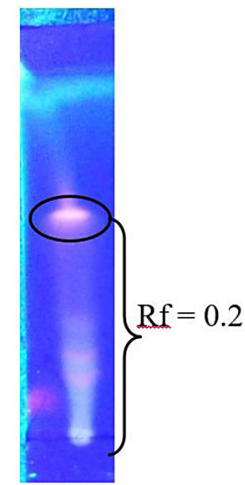

$\mathrm{N}$-hexane

(a)

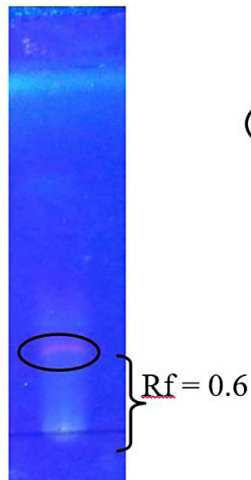

Ethyl acetate

(b)

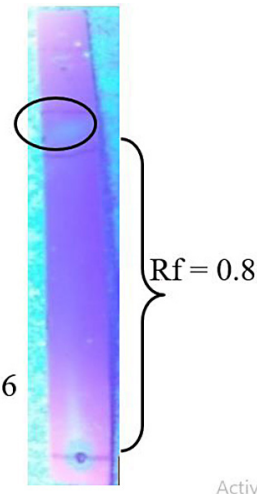

Ethanol

(c)

Figure 4. Octopus ink extract chromatography profile under the lamp with $\lambda 365 \mathrm{~nm} n$-hexane (a), ethyl acetate (b), and ethanol (c) 
Table 2. Percentage mortality of $A$. salina with concentration variation and different solution

\begin{tabular}{|c|c|c|c|c|}
\hline \multirow{2}{*}{ No } & \multirow{2}{*}{$\mathrm{ppm}$} & \multicolumn{2}{|c|}{ \% Mortality } & Ethanol \\
\cline { 3 - 5 } & & Dichloro-methane & Ethyl acetate & 100 \\
\hline 1 & 1000 & 23 & 63 & 90 \\
\hline 2 & 750 & 20 & 40 & 50 \\
\hline 3 & 500 & 13 & 20 & 10 \\
\hline 4 & 250 & 10 & 13 & 3 \\
\hline 5 & 100 & 7 & 3 & 0 \\
\hline 7 & 50 & 7 & 0 & 3 \\
\hline 9 & 0 & 0 & & 0 \\
\hline
\end{tabular}

The difference in polarity between extracts and seawater can cause problems. The extract is difficult to dissolve in water so it is necessary to use DMSO (Dimethylsulfoxide). The solvent used in dissolving the extract was DMSO 1\%. DMSO is a polar aprotic solvent used in dry freezing. Polar aprotic solvents are the solvents that have no protons for hydrogen bonding to the nucleus and will dissolve more cations than the anions. Thus, the anion is less bound by solvent molecules and more available for reaction, so the more polar a solvent is, the activation energy for ionization will be lower and the reaction rate will be faster (Wati in simanjuntak 2015). The purpose of using DMSO in other words acts as a surfactant to dissolve compounds with different polarity.

On the basis of Tables 3 and 4, the results of the analysis showed that there was a strong relationship between solvent and concentration with the percentage of mortality of shrimp larvae. Polar solvents cause higher mortality. The higher the extract concentration, the greater the larval mortality. BSLT method was carried out by exposure to the extract solution of the compound tested to Artemia larvae. In other words, the extract solution of the tested compound must dissolve completely in the living media of Artemia, namely sea water, so that the sample concentration obtained reflects the actual concentration.

$\mathrm{LC}_{50}$ (Lethal Concentration 50) is the concentration of substances that cause death in $50 \%$ of experimental animals, namely $A$. salina Leach larvae. On the basis of the $\mathrm{LC}_{50}$ values obtained, it can be said that the extracts of ethanol and ethyl acetate octopus ink in this experiment were toxic to Artemia so that it had high cytotoxic activity. Research (Meyer et al., 1982) also reported that an extract showed toxicity activity in BSLT if the extract could cause the death of $50 \%$ of test animals at concentrations of less than $1000 \mathrm{ppm}$. The $\mathrm{LC}_{50}$ values of the ethanol extract and octopus ethyl acetate ink smaller than 1000 ppm indicate that the extract has the potential for cytotoxic activity that can be developed as an anticancer drug. According to (Geran et al., 1972), a substance is said to be active or toxic if the $\mathrm{LC}_{50}$ value is less than $20 \mu \mathrm{g} / \mathrm{mL}$, whereas according to (Doyle et al., 2000) an extract is said to be active if the $\mathrm{LC}_{50}$ is less than $1000 \mu \mathrm{g} / \mathrm{mL}$.

\section{Isolation of octopus ink}

The isolation process was continued by using the ethanol extract of octopus ink. The ethanol extract was continued because it was found that $\mathrm{LC}_{50}$ dichloromethane (non-polar) was 2190 ppm, ethyl acetate (semi polar) was $947 \mathrm{ppm}$ and ethanol (polar) was $266 \mathrm{ppm}$, so ethanol extract had the greatest potential. Isolation of octopus ink extract was carried out by column chromotography. The column used was $41 \mathrm{~cm}$ long and $3.5 \mathrm{~cm}$ in diameter (Figure 5). The column chromatography method used is the wet method, where the stationary phase was dissolved using eluent first with the help of a stirring rod and then poured into a column that already contained a little eluent. Then the 3.59 gram isolate was dissolved in $50 \mathrm{~mL}$ ethanol then put into the column. The eluent used to isolate the dominant active compound from ethanol extract was eluent $n$-hexane: ethyl

Table 3. Results of $\mathrm{LC}_{50}$ octopus extract

\begin{tabular}{|l|c|c|c|}
\hline \multicolumn{1}{|c|}{ Solvent } & Linear regression equation & LC $_{50}(\mathrm{ppm})$ & Toxicity \\
\hline Dicloromethana & $\mathrm{Y}=1.357 \mathrm{x}+0.467$ & 2190 & Not toxic \\
\hline Ethyl acetate & $\mathrm{Y}=1.641 \mathrm{x}+0.116$ & 947 & Toxic \\
\hline Ethanol & $\mathrm{Y}=2.294-0.856$ & 266 & Toxic \\
\hline
\end{tabular}




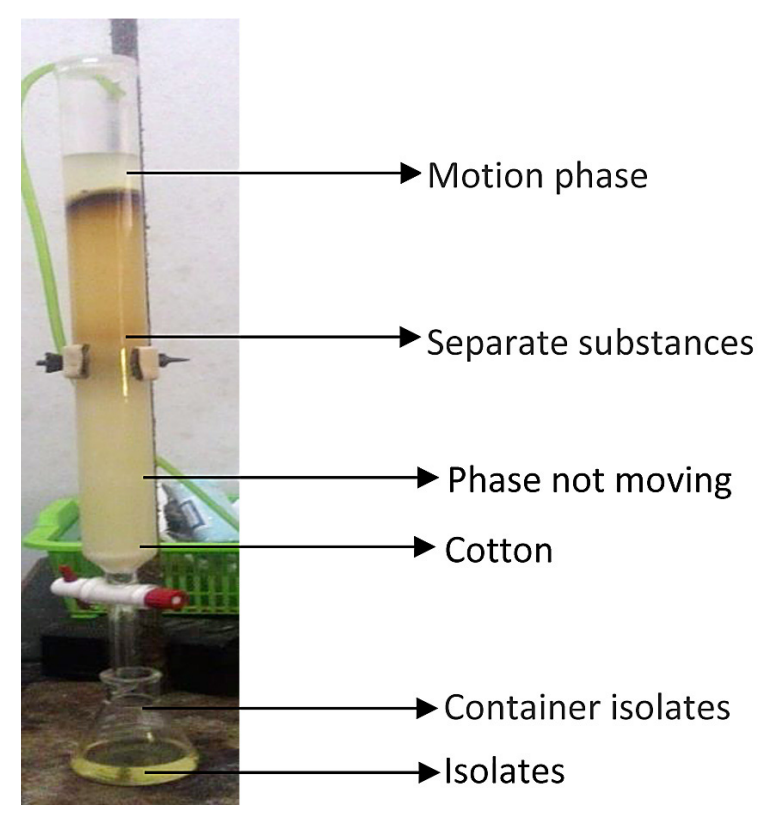

Figure 5. The process of isolating octopus ink with column chromotography

acetate: acetone (1: 4: 1). From this separation process, one dominant isolate (Figure 5) was produced and monitored by TLC (Figure 6).

From the results of the isolation, the weight of 0.1 gram of ethanol isolates $(1.25 \%)$ was obtained. Continued isolates for the cytotoxic test were ethanol fractions. The isolates were monitored by TLC with the same eluent in isolation (Figure 6). The TLC plate used was silica gel $\mathrm{F}_{254}$ containing a fluorescent indicator which emits green fluorescence when irradiated / irradiated with a UV lamp at a certain wavelength. Isolates show a single stain under a UV lamp

From the results of monitoring of ethanol isolates obtained and compared with the results

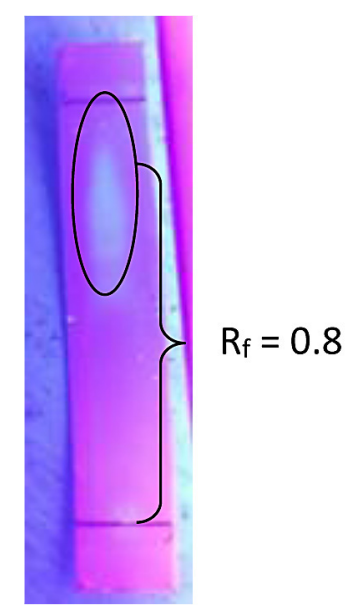

Figure 6. Octopus ink isolate chromatography profile under the $\lambda 365 \mathrm{~nm}$ lamp of monitoring conducted on ethanol extract, both have the same $\mathrm{Rf}$ value of 0.8 . Rf value can be used as evidence in identifying compounds. If the identification of the $\mathrm{Rf}$ value has the same value, the compound can be said to be well separated by column chromatography (Lispy, 2010).

\section{Test of cytotoxic activity of ethanol isolate of octopus ink (Octopus cyanea) with BSLT method}

In this study, the concentrations used were $500,250,100,50$ and $0 \mathrm{ppm}$ as controls. The control used was ethanol in order to observe the effect of solvent death on Artemia salina. If there are dead larvae in the control, it can be said that there is an effect of solvent larval death. However, in this study there were no dead larvae in the control, which could be seen from the active movements of 10 larvae in the vial. This meant the death of larvae in the pure test solution was a result of the ethanol isolates of octopus ink. Cytotoxic treatment was carried out 3 times (triplo) to increase the accuracy of the data. The data obtained was good and could be calculated statistically.

On the basis of the results of BSLT testing (Table 4) it can be seen that various concentrations of ethanol isolates of octopus ink in this study showed a different effect on mortality. There are 5 variations of experimental sample concentrations, namely 500, 250, 100, 50 and 0 ppm as controls. The results of the average mortality of shrimp larvae after incubation of 24 hours per concentration can be seen in Table 4 .

The data was then analyzed using linear regression equation by transforming the concentration data into logarithmic form and changing the percentage value of larval mortality into the probit value (Figure 7) to obtain the R2 value that is the best or close to the value of 1 . With the help of the Excel 2007 software, it shows the $\mathrm{LC}_{50}$ price of the octopus ink ethanol isolate is $45 \mathrm{ppm}$. The data processing results were obtained from linear regression equation $\mathrm{y}=0.135+2.933(\mathrm{x})$ with $\mathrm{R} 2$ $=0.988$. By entering $\mathrm{y}=5, \mathrm{x}=1.659$ obtained. Calculate $\mathrm{LC}_{50}$ was done through calculating the antilog of $\mathrm{x}$.

On the basis of Figure 7 it was found that the concentration of $500 \mathrm{ppm}$ caused the highest average mortality of larvae, while at a concentration of $50 \mathrm{ppm}$ it caused the lowest average larval mortality. In the control group there were no larval deaths. This showed that the death that 
Table 4. The number of A.salina larvae deaths in each test repetition in various treatment concentrations of octopus ink ethanol isolates (O.cyanea).

\begin{tabular}{|c|c|c|c|c|}
\hline $\mathrm{ppm}$ & Log & Avarage of death & \% Mortality & Probit \\
\hline 0 & - & 0 & 0 & 5.61 \\
\hline 50 & 1.69 & 7.3 & $73 \%$ & 5.95 \\
\hline 100 & 2 & 8.3 & $83 \%$ & 6.75 \\
\hline 250 & 2.39 & 9.6 & $96 \%$ & 8.90 \\
\hline 500 & 2.69 & 10 & $100 \%$ & \\
\hline
\end{tabular}

occurred in larvae was caused by the concentration of isolates and not caused by solvents. The BSLT method was carried out by exposure to soluble isolates which were completely dissolved in larvae living media, namely sea water, so that the sample concentration obtained illustrates the actual sample concentration.

A compound is said to be toxic and has the potential as an anti-cancer candidate in BSLT testing if it has a 24-hour $\mathrm{LC}_{50}$ value less than $1000 \mu \mathrm{g} / \mathrm{mL}$ (Meyer, et al., 1982). The octopus ink ethanol isolates have an $\mathrm{LC}_{50}$ value of $45 \mathrm{ppm}$. On the basis of the $\mathrm{LC}_{50}$ value of the octopus ink ethanol isolate, it can be said that the ethanol isolate of octopus ink is toxic and can be continued in anticancer studies in vitro. This study shows that octopus ink ethanol isolates have cytotoxic activity. This is related to octopus ink which is a natural melamine or melanoprotein which are alkaloids containing $10-15 \%$ protein which is lysosome and capable of killing cells. The previous research proves that octopus ink (Octopus vulgaris) can kill bacteria such as Staphylococcus aureus (Posangi et al., 2013). While other studies with the same phylum as Squid conducted by Lestari 2016 test the cytotoxic effect of squid ink (Loligo sumantrensis) with the BSLT method on A. Salina shrimp larvae showed an $\mathrm{LC}_{50}$ value of $174.58 \mathrm{ppm}$.

The shrimp larvae were used for 48 hours because at that age $A$. salina larvae were the most sensitive. This is because the walls of the larval cells are still soft so foreign compounds in sea water absorbed through their cell walls will immediately affect their lives. Foreign compounds that are toxic will cause death in shrimp larvae. As an egg hatching medium, A. salina used sea water with the help of aerators (with medium aeration strength) to meet the dissolved oxygen levels. The air bubbles from the aerator also function to stir the eggs evenly so that the eggs do not settle on the bottom of the container, because if this happens, the eggs will be difficult to hatch due to lack of oxygen (Purwantini et al., 2002).

In this cytotoxic activity test of octopus ink extract using A. salina test animals, the determination of $\mathrm{LC}_{50}$ values were carried out at the development stage of nauplius. According to Sorgeloos et al. (1978), the development of nauplius $A$. salina is more sensitive to toxic compounds. The pathway for exposure of toxic compounds extracts of ant nests in A. test animals. Salina begins through oral and dermal parts. In the mouth part, the toxic compound is absorbed into the digestive tract,

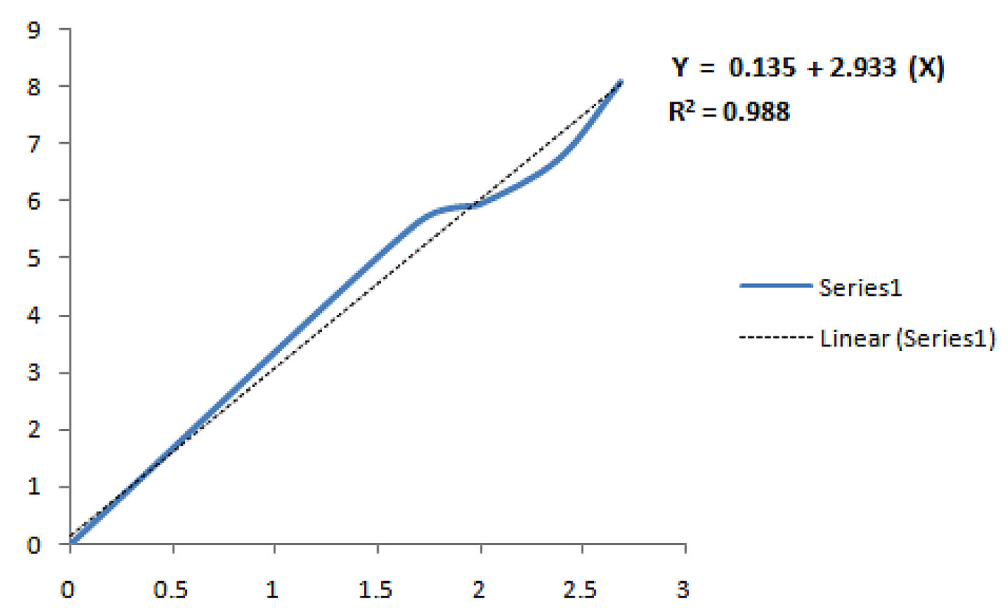

Figure 7. Relationship between concentrations of octopus ink ethanol isolates and mortality of $A$. salina 
while in the dermal part, the process of absorption through the cell membrane occurs. After the absorption process is continued with the process of distribution of toxic compounds into the body of $A$. salina, and the metabolic reaction process occurs.

This study shows that the octopus ink extract has cytotoxic effect. This relates to the compounds found in octopus ink, namely alkaloids having cytotoxic effect which can cause larval death of A. Salina (Ren et al., 2003). Alkaloid compounds have a role in inhibiting the growth of cancer cells, for example vincristine and vinblastine compounds found in the leaves of the tread. This compound acts as an antimitotic agent by binding to tubulin dimers which can interfere with the appearance of microtubules at the time of metaphase. Consequently, the mitotic process of the cell will be disrupted, so that the proliferation of cancer cells is inhibited (Mardiyaningsih, 2011).

Octopus, squid, and cuttlefish are marine animals that fall into the cephalospoda category. These animals use ink which usually contains melamine. This ink is used to protect them from predators and maintain body shape. The ink is removed from the sac located between the gills, assisted by the surge of water from the siphon located near the eye. Cephalospoda ink contains several different chemical constituents, but the main elements include melanin and mucus. In addition, ink fluids of cephalospoda are alkaloids that are not favored by predators (Hapsari, 2014). Melanin (Figure 8) is the most common compound in the ink for cephalopod classes, so it is estimated that the melanin and melanoprotein compounds obtained from octopus ink (O.cyanea) have a cytotoxic potential.

\section{CONCLUSION}

The conclusion of this study showed that the dichloromethane, ethylacetate, and ethanol extract of octopus ink had cytotoxic activity with $\mathrm{LC}_{50}$ values of $2190 \mathrm{ppm}, 947 \mathrm{ppm}$, and $266 \mathrm{ppm}$, respectively. The ethanol isolate of octopus ink (O.cyanea) has cytotoxic potential with a value of $45 \mathrm{ppm}$.

\section{Acknowledgements}

The authors would like to thank the Ministry of Technology Research and Higher Education Indonesia for providing financial support.

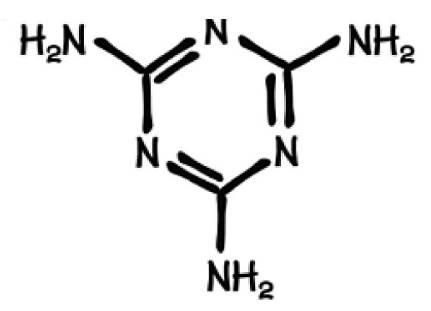

Figure 8. Structure of melanin

\section{REFERENCES}

1. Doyle A., Griffiths J. B. 2000. Cell and tissue culture for medical research. John Willey and Sons, ltd, New York.

2. Fadhli H., Teruna H.Y., Jose C. 2012. Toxicity test of Puai Basung (Alstonia spatula BL) bark extract using the brine shrimp lethality test method. J Ind Che Acta, 3(1),10-15. (in Indonesia).

3. Fitahia E. M., Raheriniaina C. E., Bazin M. A., Huvelin J. M., Loge C., Ranaivoson E., Nazih H. 2015. Anti-proliferative and pro-apoptotic effect of dichloromethane extract of Octopus vulgaris byproduct on human breast cancer cell lines. Weste Biomass Major, 6, 237-242.

4. Geran R. I., Greenberg N. H., Macdonald M. M., Schumacher A. M., Abbott B. J. 1992. Protocol for screening chemical agents and natural product against animal tumurs and other biological system. Cancer Chemother, 3, 59-61.

5. Juniarti, Osmeli D., Yuhernita. 2009. Chemical compounds, toxicity test (Brine shrimp lethality test) and antioxidants (1,1-diphenyl-2-pikrilhydrazyl) from saga leaf extract (Abrus pecatorius L). Makara sains, 13,50-54. (in Indonesia).

6. Karthigayan S., Balasubashini M. S., Sengottuvelan M., Balasubramanian T., Somasundaram S.T. 2006. Anticancer prinsiples from salivary extract of Octopus ageina. International Journal of Cancer Research, 2.

7. Kuba M., Meisel D. V., Byrne R. A., Griebel U., Mather J. A. 2003. Looking at play in Octopus vulgaris. Berliner Palaobiol Abh, 3, 163-169.

8. Lisa E. M., Maio A. D., Moroz L. I., Moccia F., Menella M. R. F., Cosmo, A. I. 2012. Characterization of novel cytoplasmic PARP in the brain of Octopus vulgaris. Bio Bull, 222, 171-181.

9. Martinez S. C. 2013. Coccidiosis and molecular basis of the immune response of common octopus. Thesis. Vigo Spanyol: Universida de Vigo, De Ecologia Biologia Animal.

10. Moeljopawiro S., Nuringtyas T. R., Noveriza R., Trisilawati O. 2007. Identification of the bioactive fraction of anti breast cancer and uterine cancer and contaminant microbes in three red fruit vetasetas 
(Pandanus Conoideus Lam). Kerjasama KemitraanPenelitian Pertanian dengan Perguruan Tinggi. Jakarta, Universitas Gadjah Mada. (in Indonesia).

11. Mardiyaninsih A., Ismiyati N. 2014. Cytotoxic activity of ethanol extract of avocado leaves (Persea Americana. Mill) on cervical cancer cells hela. Trad Med, 19(1), 24-28. (in Indonesia).

12. Mardanny M.T. 2015. Phytochemical screening and testing of cytotoxic activity from ant nest plants (Myrmecodia Beccarii Hook.F.) from Merauke Regency. Universitas Cenderawasih, Jayapura (in Indonesia).

13. Martinez S. C. 2013. Coccidiosis and molecular basis of the immune response of common octopus. Thesis. Vigo Spanyol: Universida de Vigo, De Ecologia Biologia Animal.

14. McLaughlin J.L. 1991. Crown gall tumours on potato disc and brine shrimp lethality: two simple bioassay for higher plant screening and fractionation. Methods in plant biochemistry, 6(1), 1-30

15. Meyer B.N., Ferigni N.R., Putnam J.E., Jaconsen L.B., Nichols D.F., Mc laughin J. L. 1982. Brine shimp a convenient general bioassay for active plant constituents. Planta Medica, 45, 31-34.
16. Murphy M. C. 1999. Plant products as antimicrobial agents. Clin Microbiol Rev, 12,564-5821

17. Nurhayati A. P. D., Abdulgani N., Febrianto R. 2006. Toxicity test of Eucheuma alvarezii extract against Artemia salina as a preliminary study of anti-cancer potential. Akta Kimindo, 41-46. (in Indonesia).

18. Paruntu C. P., Boneka F. B., Talare S. L. 2009. Octopus (Cephalopoda) from Sangihe Waters, North Sulawesi. Ekoton, 9(2), 13-14. (in Indonesia).

19. Posangi J., Juliatri, Bara R., Tairas J., Wuisan J. 2013. Test the antibacterial effects of squid ink (Loligo sp.) On tooth root canal bacteria. Skripsi. Manado: Fakultas Kedokteran. (in Indonesia).

20. Purwantini I., Setyowati E. P., Hertiani T. 2002. Toxicity test of ethanol extract of fruit seeds, daun mahkota dewa (Phaleria marcocarpa) against Artemia Salina Leach and active thin layer chromatography extract. Majalah Farmasi Indonesia, 101-106. (in Indonesia).

21. Ren W., Qiao Z., Wang H., Zhu L., Zhang L., 2003. Flavonoids: promising anticancer agents. Medicinal Research Review, 23 (4), 519-53.

22. Robinson T. 1995. High levels of organic plant content. ITB, Bandung. (in Indonesia). 